\title{
OPTIMIZATION AND UPGRADING WASTEWATER TREATMENT PLANTS
}

\section{Mahmoud A. El-Sheikh}

Sanitary \& Env. Eng., Menoufiya University, Shebeen Elkom, Egypt, mshafy2@yahoo.com

(Received April 21, 2011 Accepted June 12, 2011)

\begin{abstract}
Aging of wastewater treatment plants (WWTPs) reduces their efficiency and their treated effluent quality while it increases standards of safety, health and environmental protection to preserve our quality of life. Therefore, upgrading and optimization out of date WWTPs is essential to meet new standards within an economically responsible and environmentally sustainable framework. This paper reviews the most common wastewater treatment processes and their constrains that could need for upgrading. Also, it establishes procedures for optimizing and upgrading existing WWTPS including systematic approaches to find out the capacity and performance of existing processes, to determine the places of constrains, to put alternatives for overcoming limitations and evaluating different alternatives and to select the most suitable and costeffective for different kinds of processes. WWTPs in Alexandria and Damietta governorates, Egypt, have been studied for upgrading the existing situation and increase their treatment capabilities.
\end{abstract}

\section{KEYWORDS: Process limitations, Upgrading wastewater treatment,} plant optimization, treatment capacity.

\section{INTRODUCTION}

The design periods for wastewater treatment plants (WWTPs) are ranged from 20 to 60 years on two or three stages. The lifetime of the WWTPs is sometimes extended over 60 years. Existing WWTPs is aging while demand grows for more and better improved treated wastewater responding both to higher standards of safety, health and environmental protection as well as population growth. Health risks rise sharply with the ingestion of unsafe water: diseases related to water sanitation are estimated to account for $4.0 \%$ of all deaths and $5.7 \%$ of the total disease burden occurring worldwide (Vacca et al., 2005). Of course, these percentages are very high in the developing and under-developing countries. Therefore, the overloaded existing WWTPs should be rehabilitated and upgraded to retrieve their efficiency and give the required treated effluent, particularly in terms of reuse for crop irrigation, in a costeffective way. There are many reasons could be arising for upgrading of WWTPs which include: i- the need for reuse of the effluent; ii- issuing new regulations of pollution control; iii- the increase of flow to the existing WWTPs due to increasing of population or service areas; iv- the increase of pollution due to changing of activities or allowing more industrial wastewater; v- malfunction of units and/or equipments in the WWTPs; and, vi- changing the out-of-date equipments and/or technologies due to unavailability of spare parts. 
Many efforts and researches have been conducted for upgrading certain process of WWTPs to certain reasons. Existing biological activated sludge (AS) processes have been upgraded using ozone to overcome problems of high residual COD and unacceptable color from opium alkaloid processes (Sevimli et al. 2000) and also to remove of most of the micropollutants (Schaar et al. 2010). Also, coagulant and chemical doses have been applied for improving performances of existing WWTPs (Sevimli et al. 2000, De-Feo et al. 2008 and El-Sheikh et al. 2010a). Meanwhile, membrane bioreactors (MBRs) represented a main unit for remodelled the AS WWTPs (Malpe et al 2003, Yang et al. 2006, Wisniewski 2007, Fatone et al. 2008, and Grande et al. 2010). In addition, many WWTPs have been upgraded to introduce nitrification and denitrification for additional removal of ammonia and nitrogen (Berends et al. 2005, Brdjanovic et al. 2007, Vandekerckhove et al. 2008, Choi et al. 2010, Schaar et al. 2010, and Kim et al. 2010). Enhancing biological phosphorus removal (EBPR) was another reason for upgrading wastewater treatment processes in many cases (McQuarrie et al. 2004, Schuler and Jang 2007, and Reddy and Pagilla 2009). Moreover, cost-effective and natural wastewater treatment processes; such as: wetlands, oxidation ponds, lagoons and anaerobic processes have investigated for enhancement their contamination removal in many applications (Steinmann et al. 2003, Kaya et al. 2007, Katsenovich, at el. 2008, Diamantis et al. 2009, Choi et al. 2010, and El-Sheikh et al. 2010b).

The upgrading and optimization of WWTPs achieve many benefits including: allowing additional capacity in individual unit processes; achieving nitrification without additional capacity; reduction the energy use and costs associated; improving the ease and stability of plant operations; and result in an overall improvement in effluent quality. This paper reviews, studies and applies upgrading works for all kind of wastewater treatments processes.

\section{OBJECTIVE OF THE STUDY}

Upgrading of existing WWTPs requires having good backgrounds of the processes used in these WWTPs and the main constrains in these processes. This way can help in optimizing the most cost-effective method for upgrading. The objective of this paper to review the most common wastewater treatment processes and their constrains that could need for upgrading.

The procedures of WWTPs optimization will be included to apply a widespread and systematic approach to find out the capacity and performance of existing treatment units, to determine the places of constrains, to put alternatives for overcoming limitations and evaluating different alternatives to select the most suitable and cost-effective for different kinds of WWTPs. The objectives of a plant evaluation are typical for a multi-objective optimization problem: certain functions (e.g., effluent quality, reliability, and capacity) are to be maximized, whereas others (e.g., capital investment and operational costs) are to be minimized. Upgrading of the existing WWTPS is evaluated and is applied as cases studies in Alexandria and Damietta governorates during the master planning of sanitation works in all governorates of Egypt. 


\section{METHODOLOGY AND APPROACH OF WWTPs UPGRADING}

The methodology of optimization and upgrading of WWTPs include procedures to reach to the well selection and the cost-effective manner. This procedure includes many steps starting from data collection and desktop study and ending at assessment of cost-effective alternative. Figure (1) summarizes the steps of evaluation to suggest a corrective action of upgrading WWTP.This approach allows the choice of the most appropriate trade-off between cost of measures and risk of non-compliance with regulatory limits.

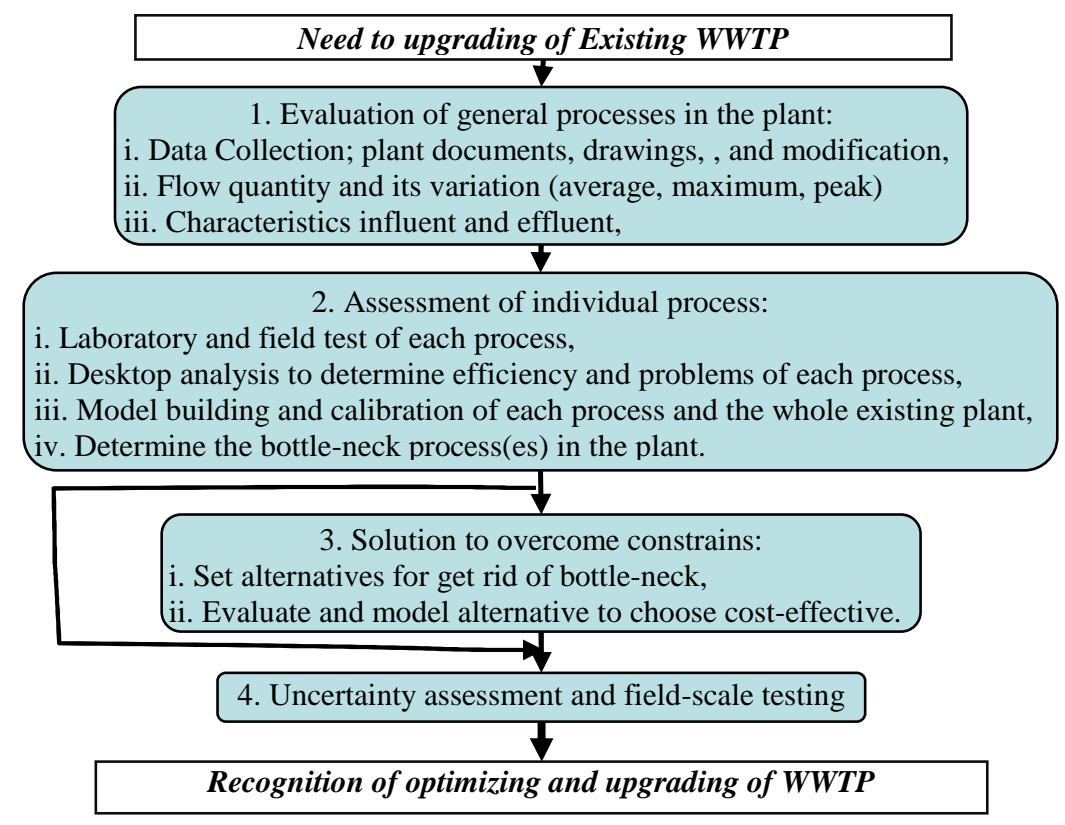

Figure 1. Steps of evaluation for upgrading WWTP.

Data collection is probably the most challenging task. In order to evaluate existing WWTPs, long term (several years) dynamic influent data are required (Benedetti et al. 2006). In absence of these data, influent data can be reconstructed using available measurements and making assumptions on the influent properties (Bixio et al., 2002). In the proposed procedure, a dynamic influent is generated using a simple model of the draining catchment (Gernaey et al., 2005). Collection of WWTP data include: plant documentations; influent and effluent wastewater characteristics for last 3 years; wastewater flow and its variation of 3 years; and design criteria of the existing processes.

After data collection, desktop studies should be started to assess the existing processes and facilities based on the historical data. The desktop studies should include many parameters such as: the last process loading and performances; capacity constrain factors for each process; any useful information in subsequent detailed evaluation. Laboratory and field tests for different processes are helpful to review the performance of the WWTP facilities. Moreover, online monitoring techniques could 
enable identification of short-term variations that may impact plant performance. From the desktop studies, initial and detailed evaluations should be conducted for each treatment unit and for the plant as a whole. The evaluations should cover both capacity and performance. They follow the sequence of each process and operations according to the flow diagram of the WWTP, including sludge treatment processes. The suggested correction action should be re-evaluated and modeled to test its expected performance and cost-effective.

\section{LIMITATIONS OF EXISTING TREATMENT PROCESSES AND SUGGESTED CORRECTIVE ACTIONS}

Hydraulic condition of the WWTPs; the hydraulic study in WWTPs include dividing the flow between the parallel modules and/or units; determining the level of water in units (with suitable free boards); and head losses in flow control devices (valves, gates, weirs, flow-meters, etc.), distributors, units and their connecting pipes. The plant hydraulic assessment helps to identify the hydraulic bottlenecks which include miss-distribution among parallel modules and/or units, resulting in overloading of some units and under-loading of others. High head losses represented another hydraulic problem that could lead to decreasing the free board (sometimes flooding) in the upstream units and increasing it at the downstream units. Treatment units could safely have high capacity while the connecting channels, pipes and/or pumps could have flow restrictions. WWTP hydraulic model is used to estimate the water level in different units under all flow fluctuations. Modeling usually includes all units, interconnection and control devises. AS Models (ASM) were extensively used to examine WWTPs' upgrade options (Ladiges and Günner 2003). Hydraulic modeling helps in finding the constrains, predicting effect of their changes, examining alternatives and choosing the cost effective solution. Using models investigate the likely impact of changes in a "virtual" environment, where there are no cost or permit restrictions before moving ahead with the changes at the full scale.

Hydraulic capacity upgrading of WWTPs overcomes hydraulic bottlenecks and reduces the head losses in plants. There are many methods used to overcome and upgrade the WWTPs hydraulic problems which include: i) increase freeboard by raising walls; ii) reduce head losses by removing unnecessary flow distributors, flow control structures, redundant flow meters, and changes in the flow direction; iii) optimize and/or replace the flow control and distribution structures; iv) modify shape and/or size, or replacing the existing connecting system with more hydraulically efficient; v) adjust the inlet/outlet structures of unit process; vi) improve the performance of the control and flow meters (flume, venturi meter, valves and gates); vi) regulate the effluent weirs of primary and secondary settling tanks; viii) adjust the hydraulic loads of unit processes based on performance criteria; and ix) apply intermediate pumping if extra hydraulic capacity is needed. Some WWTPs receive highly variable hydraulic and organic loadings, resulting in overloading and less than optimum treatment. Flow equalization tank could be used to improve treatment plant efficiency since the variable loading will be dampened.

Preliminary treatment facilities; WWTPs usually includes influent lift stations, screens, pre-aeration basins, oil and grease removal systems, grit removal systems, and 
flow measurement equipment. Very fine screening may even be used to replace grit removal (Stephenson et al., 2002). In addition, fine screens have been shown to remove $15-30 \%$ total suspended solids (SS), 15-25\% $\mathrm{BOD}_{5}$, and 10-20\% bacteria loadings (Metcalf and Eddy, Inc., 2003). Poor performance of screens can result in many problems such as: Plugging valves, nozzles, channels, pipelines, pumps and appurtenances; Fouling of pumps, monitoring equipment, and other processes; Obnoxious odors, flies, and other insects to accumulate around the screen; Inadequate velocity that may cause the build-up of silt and grit in channels (Qasim, 1999), rag build-up on mixers and mechanical surface aerators (U.S. EPA, 2003), reduced effluent quality due to loss of bioreactor volume (Stephenson et al., 2002), hair and small fibrous materials reformulate in aeration tanks into ropes and larger agglomerations (Reddy and Pagilla, 2009). There are many actions to overcome the screen constrains which include: increasing frequency of removal and disposal of screenings; increase maintenance of poor reliability; repair or replace rust screen bars; adjust flow velocity upstream and inside screen; install mechanically cleaned coarse screens or other protective devices; install washing systems to separate the screening material; and install additional screen for overloading.

Malfunction of grit removal systems can result in accumulation of inert materials in settling, aeration and digesting tanks creating a significant reduction of the tank volume and its treatment capacity. Also, grit could scratch or break equipment in the treatment facilities resulting in wearing of pumps, mixers and other equipment, and deficiency in their performance and increasing maintenance. Optimizing of the grit removal depends on the faults that appear during the visual investigation. Upgrading of the grit removal unite could include: i) rearranging of the hydraulic inlet or outlet process; ii) improve grit conveyance system capacity; iii) adjust horizontal velocity in grit chamber; iv) prevent short-circuiting in chamber; v) uniformly distributing of surface loading rate; vi) increase or add new surface area; vii) modifying or replacing deteriorate structures and grit conveying equipment.

Primary settling tanks (clarifiers); they are mainly used to remove settleable solids and particulate BOD. There are many factors could reduce the performance of the primary settling such as: imbalanced flow divided; short-circuiting and poor hydrodynamic characteristics; high surface loading rate; undersized clarifier; floatable materials; insufficient sludge removal; unadjusted effluent weirs; and non-settleability characteristics of wastewater (Wahlberg, 2006). The removal of a higher volatile fraction (active biomass) in the primary settling could result in lower mixed liquor suspended solids (MLSS) and reduce the organic loading to the biological system. Table (1) summarizes the problems that could be faced in the primary settling and common methods for optimizing its performance.

Different alternatives could be considered to increase capacity and improve performance of primary treatment, including: i) chemically assisted primary sedimentation -CAPS-; ii) ballasted flocculation with silica sand; iii) lamella plate settlers; iv) new filter type screens; and v) addition of one new primary sedimentation tanks (Reddy and Pagilla, 2009). Five criteria procedure could be used in order to select the best combination of coagulant and dose which include: COD percentage removal, sludge volume after $2 \mathrm{~h}$, coagulant dose, coagulant cost, $\mathrm{pH}$ percentage variation (De-Feo et al. 2008). 
Table 1. Effect Problems in Settling and Processes of Optimizing.

\begin{tabular}{|c|c|c|}
\hline Problem & Effects & Processes of optimizing \\
\hline $\begin{array}{l}\text { Unbalanced flow } \\
\text { divided }\end{array}$ & $\begin{array}{l}\text { Overload in some units and } \\
\text { under-load in others resulting in } \\
\text { poor performance }\end{array}$ & $\begin{array}{l}\text { Adjust the distribution unit and } \\
\text { valves to have hydraulically equal } \\
\text { flow for all units }\end{array}$ \\
\hline $\begin{array}{l}\text { High surface loading } \\
\text { rate }\end{array}$ & $\begin{array}{l}\text { Poor settling of light density } \\
\text { particles }\end{array}$ & $\begin{array}{l}\text { Use chemical flocculent or increase } \\
\text { surface area }\end{array}$ \\
\hline Floatable materials & $\begin{array}{l}\text { Foaming problems and/or } \\
\text { interfacing with downstream } \\
\text { processes }\end{array}$ & $\begin{array}{l}\text { Adjust skimming tools or install } \\
\text { new one; repair and adjust the outlet } \\
\text { weir }\end{array}$ \\
\hline $\begin{array}{l}\text { Unadjusted effluent } \\
\text { weirs }\end{array}$ & $\begin{array}{l}\text { Non-uniform flow distributing in } \\
\text { tank resulting poor settling }\end{array}$ & $\begin{array}{l}\text { Adjust effluent weirs or install new } \\
\text { one. }\end{array}$ \\
\hline $\begin{array}{l}\text { Short-circuiting and } \\
\text { poor hydrodynamic } \\
\text { characteristics }\end{array}$ & $\begin{array}{l}\text { Dead zone in tank and poor } \\
\text { settling }\end{array}$ & $\begin{array}{l}\text { Introduce or repair baffles at inlet to } \\
\text { uniform distribute flow; rearrange } \\
\text { inlet and outlet weirs. }\end{array}$ \\
\hline Undersized clarifier & Poor settling performance & $\begin{array}{l}\text { Use chemical additives or install } \\
\text { new tank }\end{array}$ \\
\hline $\begin{array}{l}\text { Insufficient sludge } \\
\text { removal }\end{array}$ & $\begin{array}{l}\text { Digestion of sludge produce } \\
\text { gases (odour) that disturb the } \\
\text { settling process }\end{array}$ & $\begin{array}{l}\text { Increase sludge removal, increase } \\
\text { sludge capacity, increase diameter } \\
\text { of sludge pipe, repair sludge } \\
\text { scrapper tires, motor, blade. }\end{array}$ \\
\hline $\begin{array}{l}\text { Non-settleability } \\
\text { characteristics and bio- } \\
\text { flocculation problems } \\
\text { of wastewater }\end{array}$ & $\begin{array}{l}\text { Poor settling process due to } \\
\text { increasing volatile suspended } \\
\text { solids }\end{array}$ & $\begin{array}{l}\text { Remove co-settling of WAS with } \\
\text { primary sludge; remove heavy } \\
\text { metals from the influent ; reduce } \\
\text { chlorine dose in the RAS line and } \\
\text { change place return flows } \\
\text { downstream of tank. }\end{array}$ \\
\hline $\begin{array}{l}\text { Poor sludge } \\
\text { settleability }\end{array}$ & $\begin{array}{l}\text { Floatation of sludge; poor } \\
\text { effluent quality }\end{array}$ & $\begin{array}{l}\text { Control growth of filamentous } \\
\text { organisms; add polymer or } \\
\text { coagulants; }\end{array}$ \\
\hline
\end{tabular}

Attached or fixed growth processes; Trickling filters (TF) and rotating biocontactors (RBCs) employ attached microorganisms in the removal of organic material and nutrients present in the wastewater. These processes are preferred in many wastewater biodegradation because of their cost effectives and low operation and maintenances. The constrains in the attached growth processes include high organic loading; odor generation; non-uniformly distributing wastewater from rotating arms, clogging part of internal media; insufficient aeration; and flies and insects accumulation. Table 2 shows the effect of such constrains and required action to upgrade these processes and performance.

Biofilm system could be used to upgrade existing ponds by introducing planted aggregate dams in the ponds (Steinmann et al. 2003, Katsenovich, at el. 2008). The biofilm adhered to plans and aggregate showed high reduction of organic, $\mathrm{NH}_{4}-\mathrm{N}$ and pathogenic populations; especially helminthes eggs, and enhancing the filtration of algae. In addition, aerated submerged bio-film (ASBF) modules offer the potential for a low-cost upgrade to lagoon systems leading to better odor and pollution control (Choi et al. 2010). The ASBF enhances the performance of wastewater treatment lagoons through the addition of structure that encourages the growth of heterotrophic and 
autotrophic bacteria (as a nitrifying bacterial bio-film) on submerged bio-film, and through supplying air directly to the submerged bio-film that enhance the oxygen transfer to the bacteria in the bio-film. Moreover, biofilm in TF were used for removal of algae from waste stabilization pond effluents (Kaya et al. 2007). TF couples biological and mechanical filtration to effectively reduce BOD and SS in the effluents, producing an effluent suitable for reclamation (landscape irrigation and soil conditioning).

\section{Table 2. Constrains effect in Attached Growth Processes and action of upgrading.}

\begin{tabular}{|l|l|l|}
\hline Constrains & Effects & Upgrading action \\
\hline $\begin{array}{l}\text { High organic } \\
\text { loading }\end{array}$ & $\begin{array}{l}\text { Reduce performance, increase } \\
\text { anaerobic reactivity, odor } \\
\text { generation. }\end{array}$ & $\begin{array}{l}\text { Increase performance of } \\
\text { upstream process, increase } \\
\text { return flow fraction, introduce } \\
\text { ventilation, increase or replace } \\
\text { media and suspended growth } \\
\text { system, install new units. }\end{array}$ \\
\hline $\begin{array}{l}\text { Poor distribution of } \\
\text { wastewater on TF } \\
\text { surface }\end{array}$ & $\begin{array}{l}\text { Ponding media, reduce effluent } \\
\text { quality, flies and insects } \\
\text { accumulation }\end{array}$ & $\begin{array}{l}\text { Adjust rotating arms, increase } \\
\text { return flow fraction, use driven } \\
\text { motors. }\end{array}$ \\
\hline $\begin{array}{l}\text { Insufficient } \\
\text { aeration }\end{array}$ & $\begin{array}{l}\text { Increase anaerobic reactivity, } \\
\text { odor generation }\end{array}$ & $\begin{array}{l}\text { Reduce hydraulic loading; } \\
\text { introduce ventilation }\end{array}$ \\
\hline $\begin{array}{l}\text { Mechanical } \\
\text { problems in RBCs }\end{array}$ & $\begin{array}{l}\text { Poor performance due to air- } \\
\text { drive systems for shaft rotation }\end{array}$ & $\begin{array}{l}\text { Adjust mechanical system, } \\
\text { replace driving motors and/or } \\
\text { rotating shafts }\end{array}$ \\
\hline
\end{tabular}

The suspended growth (activated sludge) process; It is the most widely used biological system for the treatment of municipal wastewater. It uses a microbial group of many organisms to get rid of pollutant through: biodegradation of organic carbon (BOD) to carbon dioxide and water; conversion of organic nitrogen to ammonia nitrogen (ammonification); oxidation of ammonia nitrogen to nitrate nitrogen (nitrification); reduction of nitrate nitrogen to nitrogen gas (denitrification); removing phosphorus in excess of metabolic needs (EBPR). There many adverse effects could reduce the performance and efficiency of the suspended growth process. Table 3 summarizes the problems in AS processes and suggested method for optimizing the process.

Increasing the sludge return (RAS) ratio and increasing oxygen concentration in the aeration basins could be used to optimize existing AS process with significant improvement in MLVSS, SVI and COD efficiency. After both procedures, microbiological examinations show that there is a high density and acceptable removal level of filamentous bacteria, which is the most significant evidence of foaming and bulking, which might be responsible for low or high SVI and low MLVSS/MLSS ratio (Meriç et al. 2002), see Figure 2.

Problems associated with poorly settling solids include decreased disinfection efficiencies, and increased risks to downstream ecosystems and public health (Martins et al. 2004). Poor settleability of completely AS bioreactor could be upgraded by 
converting its front to an anaerobic selector for reducing filamentous organism content and encouraging the growth of polyphosphate accumulating organisms, resulting in increasing polyphosphate content -EBPR- and hence biomass density (Schuler and Jang 2007). In addition, increasing solids residence time (SRT) can improve settleability by increasing biomass density and increasing non-volatile SS (NVSS) content (because retaining biomass for long periods results in accumulation of NVSS, while most of VSS converts to $\mathrm{CO}_{2}$ due to endogenous degradation of organic carbon) (Ekama et al. 2004). Moreover, Available sufficient bioreactor capacity in traditional AS WWTPs can be upgraded for partial or even full nitrogen removal (nitrification and denitrification) within the existing bioreactor through reducing WAS by about $50 \%$ (increase in SRT); creation of anoxic zone in the front of the bioreactor; and internal recirculation of about 300\% (Brdjanovic et al. 2007).

Table 3. Problems in activated sludge processes and suggested method for upgrading the process.

\begin{tabular}{|c|c|c|}
\hline Problem & Effects & Optimization \\
\hline $\begin{array}{l}\text { Inadequate biological } \\
\text { oxidation inside the } \\
\text { aeration tank }\end{array}$ & $\begin{array}{l}\text { Incomplete biodegradation of } \\
\text { organic matter, increase } \\
\text { filamentous organism; produce } \\
\text { odor, poor performance of process }\end{array}$ & $\begin{array}{l}\text { Repair and adjust air diffused pipes } \\
\text { and/or diffuser; aerators need to be } \\
\text { maintained; adjust aeration rate control } \\
\text { system; remove scum accumulation; } \\
\text { introduce new aeration unit(s); } \\
\text { adequate placing of the impellers need } \\
\text { to be done }\end{array}$ \\
\hline $\begin{array}{l}\text { Insufficient mixing in } \\
\text { reactor }\end{array}$ & $\begin{array}{l}\text { Settling of solids in the reactor; } \\
\text { short-circuit of flow; bad effluent } \\
\text { quality }\end{array}$ & $\begin{array}{l}\text { Increase mixing of influent and RAS; } \\
\text { adjust inlet and outlet arrangement; }\end{array}$ \\
\hline $\begin{array}{l}\text { Extreme back mixing } \\
\text { in the reactor }\end{array}$ & $\begin{array}{l}\text { Consume more energy; poor } \\
\text { settleability of MLSS }\end{array}$ & $\begin{array}{l}\text { Introduce or repair baffle of the } \\
\text { bioreactor, adjust inlet and outlet } \\
\text { arrangement. }\end{array}$ \\
\hline $\begin{array}{l}\text { Overloading in peak } \\
\text { and wet weather } \\
\text { flows }\end{array}$ & $\begin{array}{l}\text { Overloading organic loads, } \\
\text { inadequate treatability }\end{array}$ & $\begin{array}{l}\text { Introduce equalization tank, use step } \\
\text { feed or sludge re-aeration during peak } \\
\text { flows }\end{array}$ \\
\hline $\begin{array}{l}\text { Insufficient readily } \\
\text { biodegradable } \\
\text { substrate }\end{array}$ & $\begin{array}{l}\text { Reduce settleability; improper F/M } \\
\text { ratio; poor effluent quality }\end{array}$ & $\begin{array}{l}\text { Adjust recycle loads, add carbon souse; } \\
\text { add chemical precipitators }\end{array}$ \\
\hline Small bioreactor size & $\begin{array}{l}\text { Reduce phosphorus removal and } \\
\text { effluent quality }\end{array}$ & $\begin{array}{l}\text { Add chemical precipitators; increase } \\
\text { bioreactor unit }\end{array}$ \\
\hline $\begin{array}{l}\text { Oversize bioreactor } \\
\text { capacity }\end{array}$ & $\begin{array}{l}\text { Increase filamentous micro- } \\
\text { organism; poor settleability }\end{array}$ & $\begin{array}{l}\text { Adjust the capacity to zone volume of } \\
\text { different processes kind (Anaerobic, } \\
\text { anoxic, or aerobic) }\end{array}$ \\
\hline $\begin{array}{l}\text { Floatable } \\
\text { accumulation on } \\
\text { bioreactor }\end{array}$ & $\begin{array}{l}\text { Insufficient oxidation of } \\
\text { bioreactor; increase filamentous } \\
\text { organism; poor settleability; } \\
\text { flooding of foam }\end{array}$ & $\begin{array}{l}\text { Introduce scum collector; prevent } \\
\text { recycling foam and scum; introduce } \\
\text { selectors; introduce RAS chlorination; } \\
\text { add polymers }\end{array}$ \\
\hline $\begin{array}{l}\text { Poor sludge } \\
\text { settleability }\end{array}$ & Poor effluent quality & $\begin{array}{l}\text { Change operating conditions, use } \\
\text { selectors, add polymer, or chlorinate } \\
\text { RAS. }\end{array}$ \\
\hline $\begin{array}{l}\text { High DO or nitrate } \\
\text { inputs }\end{array}$ & $\begin{array}{l}\text { Poor settleability; insufficient } \\
\text { denitrification }\end{array}$ & $\begin{array}{l}\text { Adjust aerator mechanism; reduce } \\
\text { recycling; introduce DO exhaustion } \\
\text { zone }\end{array}$ \\
\hline
\end{tabular}


Oxidation ponds can also be upgraded and increased its hydraulic capacity in a cost effective method by converting it to aerated lagoon that achieve full secondary treatment effeiciency. Implementing baffles and complete mix zones increase the treatment capacity of existing aerated lagoons (Nelson 2008). The integrated fixed film AS (IFAS) is an increasingly popular modification of conventional AS, consisting of the addition of solid media to bioreactors to create hybrid attached/suspended growth systems. The IFAS is an attractive option for retrofitting many existing facilities, to improve nitrification-denitrification capacity without construction of new reactors. The IFAS demonstrated good settleability in AS processes and EBPR (McQuarrie et al. 2004, Kim et al. 2010). IFAS installation could also improve EBPR as it allows for a short SRT in the suspended growth, which favors biomass phosphorus accumulation (Onnis-Hayden et al. 2008, Kim et al. 2010).
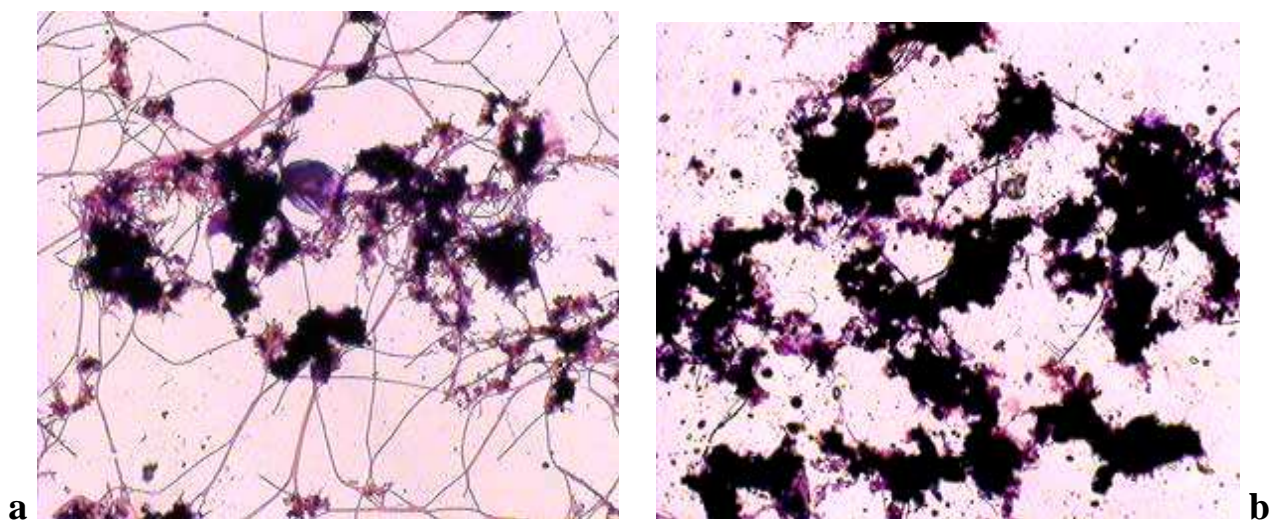

Figure 2. The microscopic observation before (a) and after (b) increasing RAS ratio in bioreactor.

MBRs system, which combines the AS process and the separation of biomass from treated water on porous membranes, is experiencing an increasing success on markets (Le-Clech at el. 2006, Yang at el. 2006). The MBR process reduces the importance for biomass sedimentation, thus allowing a significantly smaller tank to be used for the bio-treatment process. In particular, MBRs allow to treat wastewaters for reclamation and reuse (Wisniewski, 2007, Pearce, 2008), since the membrane barrier removes essentially all particulates above the pore size rating of the membrane. As the installations scale of MBR technology has increased, there has been a steady downward trend in membrane prices, which is still continuing (Cote et al. 2004). The upgraded existing WWTP could be remodelled primary and secondary settlers and biological reactors using MBRs process and achieving complete recovery of existing WWTP structures (Fatone et al. 2008, Grande et al. 2010). The primary settler is readapted the anoxic reactor, while the aerobic treatment is sequentially remodelled biological reactor and at the actual secondary settler. The ratio anoxic zone/reactor global volume could be in the range of $20-25 \%$ with using a probe for measuring redox potential to control the de-nitrification process and also using underwater stirring in order to avoid deposit formation (Grande et al. 2010).

Cost effectives MBR design require optimization of the process tank volume where a small process tank will provide immediate capital cost savings, but will 
increase the organic loading $(\mathrm{F} / \mathrm{M})$ and increase costs for maintaining membrane permeability (Trussell et al., 2005). Regardless of mean cell or hydraulic residence times, MBR effluents contain undetectable SS concentrations $(<2 \mathrm{mg} / \mathrm{L})$ and have low COD because of the filtration provided by the membrane (Trussell et al., 2006). When MBRs process fails, the effluent quality is typically unaffected, but the effluent flow rate decreases due to severe membrane fouling. But, when a conventional AS system with a gravity secondary clarifier fails, the effluent quality deteriorates. Because of the very limited area, MBR was used to upgrade extended aeration plant in Monteray WWTP, North Carolina, USA (Sparks 2010). The MBR allowed for the plant to utilize much of its existing infrastructure where each train of the extended aeration plant was transformed to an anaerobic, primary anoxic, aeration and secondary anoxic zone. The remaining tank volume is utilized for sludge holding and digestion.

Optimization of secondary settling tank (SST); it needs to reduce or adjust the suspended solid surface loading, but the optimization of the suspended growth process usually focuses on selection of the most cost effective design MLSS concentration. As the MLSS concentration increases the size of the aeration basin decreases, but SST surface area increases. In other words, while the cost of aeration tank decreases, the cost of the SST increases. Therefore, the optimum MLSS concentration is the one that results in minimum total cost. Incomplete denitrification in the bioreactor could result in occurring it in SST and produce small gas bubbles that burst at the water surface with floating sludge on the surface. The increasing of SS and nitrate concentration in effluent strongly indicate denitrification occurring in SST (Wahlberg, 2001). Floating sludge is caused by denitrification, growth of specific organisms, by the presence of poorly degradable surfactants or nutrient limitations. Other constrains and actions to overcome in SST are shown in Table (1).

Filtration processes are used in WWTPs to remove non settleable solids. Filtration has become an integral component in the wastewater treatment process, especially for reuse of treated wastewater. There are two main types of filtration: surface filters that have openings ranging 10 to $100 \mu \mathrm{m}$, and membrane filters with range 0.0001 to $1 \mu \mathrm{m}$ (Metcalf and Eddy, 2003). The surface filters are typically gravity driven while all membrane filters are pressurized. Improper filtration performance can result in increasing effluent particle concentration and lowering ultraviolet (UV) transmittance value, which can affect disinfection system performance and result in residual coliform concentrations (Dietrich et al. 2003). Other constrains of filtration are presented in Table (4).

Disinfection is used to destroy bacteria and microorganisms; especially diseasecausing organisms by using many kinds of disinfectants including chlorine gas (most common), sodium hypochlorite, chloramination, UV light, or ozonation. The application of ozonation $\left(0.6 \mathrm{~g} \mathrm{O}_{3} \mathrm{~g} \mathrm{DOC}^{-1}\right)$ could also used to upgrade WWTPs for removal of most of the micropollutants, especially for compounds that were not degraded in the traditional biological process (Schaar et al. 2010). Disinfection is usually the last step in treating wastewater. Therefore, the problems in disinfection result in increasing microorganisms in the water body receiving the effluent and increasing diseases in the surrounding environments. There are many problems could arising from disinfection which include; poor mixing, insufficient concentration/contact time, high interference of solids/algae with disinfectants, 
formation of disinfection by-products (DBPs), fouling to UV lamps, and declining and/or delaying of UV lamp. Upgrading and optimization of the previous problems could respectively include adjust turbulence and mixing in contact tanks, increase doses and/or contact time, improving removal solids in pre-units, changing type of disinfectant and/or removing DBPs precursors, adjust fouling control, and adjust UV lump and its power supply.

Table 4. Filtration Process Constraints, causes and upgrading.

\begin{tabular}{|c|c|c|}
\hline Constraints & Causes & Upgrading \\
\hline $\begin{array}{l}\text { Poor filtration } \\
\text { effluent quality }\end{array}$ & $\begin{array}{l}\text { High loading rates, high solid } \\
\text { load; malfunction upstream } \\
\text { processes }\end{array}$ & $\begin{array}{l}\text { Decrease loading rates; add } \\
\text { prefiltration coagulats and } \\
\text { flocculation; introduce additional } \\
\text { filters. }\end{array}$ \\
\hline $\begin{array}{l}\text { Balling of suspended } \\
\text { solid in filter }\end{array}$ & $\begin{array}{l}\text { High solid loading; clogging } \\
\text { filter media }\end{array}$ & $\begin{array}{l}\text { Reduce the filter run time; increase } \\
\text { number of washing per day }\end{array}$ \\
\hline $\begin{array}{l}\text { Accumulation of } \\
\text { grease }\end{array}$ & $\begin{array}{l}\text { High grease contents; deficit } \\
\text { pre-units }\end{array}$ & $\begin{array}{l}\text { Introduce grease removal in front } \\
\text { units }\end{array}$ \\
\hline $\begin{array}{l}\text { Cracking of filter } \\
\text { media }\end{array}$ & $\begin{array}{l}\text { High solid loading; } \\
\text { inadequate rewashing } \\
\text { process }\end{array}$ & $\begin{array}{l}\text { Reduce loading rates; increase } \\
\text { backwash rates and numbers; } \\
\text { replace filter media }\end{array}$ \\
\hline $\begin{array}{l}\text { Escaping of filter } \\
\text { media. }\end{array}$ & $\begin{array}{l}\text { High backwashing pressure } \\
\text { and rates }\end{array}$ & $\begin{array}{l}\text { Media in each filter could be } \\
\text { replaced. }\end{array}$ \\
\hline $\begin{array}{l}\text { Accumulation of } \\
\text { supporting media }\end{array}$ & $\begin{array}{l}\text { Cracking of filter media; } \\
\text { non-uniform distribution of } \\
\text { filtration and/or backwashing }\end{array}$ & $\begin{array}{l}\text { Rearrange supporting media; } \\
\text { adjust filtering and washing rates; } \\
\text { replace underdrain system. }\end{array}$ \\
\hline $\begin{array}{l}\text { Fouling of filtration } \\
\text { media }\end{array}$ & $\begin{array}{l}\text { High turbidity and/or grease } \\
\text { loading; inadequate } \\
\text { rewashing process }\end{array}$ & $\begin{array}{l}\text { Reduce the filter run time; increase } \\
\text { number of washing per day }\end{array}$ \\
\hline Membrane fouling & $\begin{array}{l}\text { High concentration of metal } \\
\text { oxides, and other } \\
\text { components; polarization } \\
\text { contains on surface and/or } \\
\text { within membrane pores. }\end{array}$ & $\begin{array}{l}\text { Introduce pretreatment of influent; } \\
\text { increase membrane backflushing; } \\
\text { limit bacteria activity by } \\
\text { disinfection; chemical cleaning of } \\
\text { the membranes }\end{array}$ \\
\hline Membrane damage & $\begin{array}{l}\text { Chemical substances that can } \\
\text { react with the membrane of } \\
\text { biological agents }\end{array}$ & $\begin{array}{l}\text { Inhabit scaling; use chemical does } \\
\text { not react with membranes; reduce } \\
\text { concentration of does. }\end{array}$ \\
\hline
\end{tabular}

Sludge treatments include many processes such as: thickening, stabilization, digestion, conditioning, dewatering, and disposal. Thickening is generally accomplished by physical means, including co-settling, gravity settling, floatation, centrifugation, gravity belt, and rotary drum. Gravity thickener is the most commonly used method among the thickening processes (Turovskiy and Mathai, 2006). Sludge digestion goals have recently become biogas production, phosphorus recovery from the supernatant and producing easily dewaterable sludge; in addition to reducing the volatile solids content and pathogens. Dewatering is done to remove the water fraction 
from the sludge, and it provides greater volume reduction than thickening (Metcalf and Eddy, 2003). Solids handling processes account for up to $40 \%$ of the capital costs, $50 \%$ of the operating costs, and $90 \%$ of the operational problems at a WWTP (Reddy and Pagilla, 2009). The variations in sludge quantity and quality, along with poor judgment of sludge characteristics, can result in poor equipment performance and severe operating problems (Turovskiy and Mathai, 2006). Other problems in sludge treatment include: increasing water contents and fining (small particles); high solids loading rates; turbulence and short circuits in thickening; high foaming grit and scum accumulation; repulsion of sludge due to negative surface charges; high sludge depth; long storage and high septicity of sludge; low temperature, alkalinity, SRT and insufficient mixing in digesters; reduction void space inhibit movement of water and increase resistance to dewatering. The overcome and upgrade of these operation conditions in sludge dewatering processes offer many benefits and reduction in the volume of sludge and improvements in the properties of produced sludge.

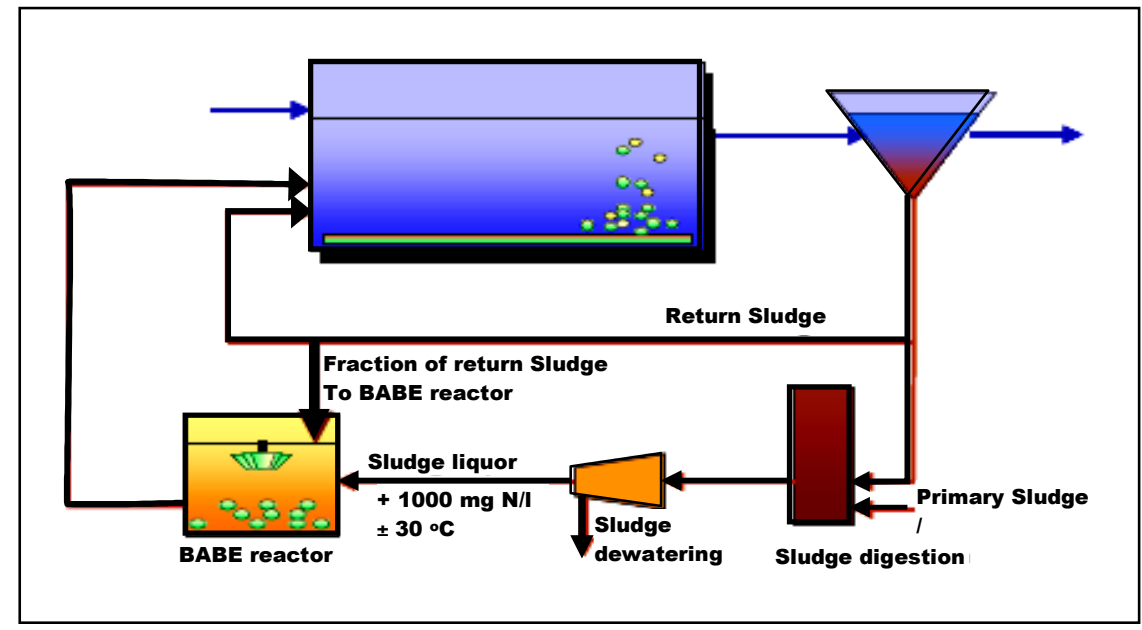

Figure 3. Reduction of recycled loads from sludge treatment in a side stream process.

The reintroduction of recycled sludge to the liquid treatment trains in WWTPs often results in increase in hydraulic, solids, organic and nutrient load, and must be considered carefully during the design and operation of WWTPs to meet the effluent quality requirements and to operate the treatment processes properly (Metcalf and Eddy, 2003). SS returned from anaerobic digesters was found to contribute 18 to $71 \%$ of plant influent loading, while accounting for only $0.3-1.4 \%$ of the flow. Return flows from thermal conditioning have been found to contribute $7-21 \%$ of the total plant $\mathrm{BOD}_{5}$ loading, but only $0.5-1.0 \%$ of the flow (Reddy and Pagilla, 2009). The high concentration pollutants (nitrogen and carbon sources) returned and/or recycled from digested and retuned sludge could be treated in a side stream process (Bio Augmentation Batch Enhanced -BABE- Figure 3) (Berends et al. 2005). This process could increase the nitrification-denitrification at WWTP with saving about $50 \%$ in area requirement and reducing the recycled loads from sludge treatment. 


\section{UPGRADING EXISTING WWTPS DURING MASTER PLANNING OF SANITATION WORKS IN EGYPT}

Upgrading of the existing WWTPS was one of the main tasks during the master planning of sanitation works in all governorates of Egypt. Two cases will be mentioned as examples for upgrading, in Alexandria and Damietta governorates. In Alexandria, the total capacity of treating wastewater was about $900,000 \mathrm{~m}^{3} / \mathrm{d}$ in four existing WWTPs; about $500,000 \mathrm{~m}^{3} / \mathrm{d}$ in the biggest one (Eastern WWTP), $360,000 \mathrm{~m}^{3} / \mathrm{d}$ in Western WWTP, and the remaining in two small WWTPs (Misr Consult, 2008). According the procedure stated above for upgrading, the study showed that the preliminary treatment facilities at the Eastern WWTP (screens, pre-aeration, oil and grease removal systems) was working well and did not need to upgrade for future expected flow $\left(805,000 \mathrm{~m}^{3} / \mathrm{d}\right)$. Meanwhile, it suggested to upgrade the primary settling processes by using coagulants or adding new settling units. Adding new settling units was the cost effective for upgrading the plant. Upgrading of the Eastern WWTP also included adding new suspended growth biological process (selector, aerator, anoxic and final settling) and mechanical dewatering for upgrading the effluent to agree with the Egyptian laws. For the Western WWTP $\left(775,000 \mathrm{~m}^{3} / \mathrm{d}\right.$ as future expected flow), upgrading required adding new settling and suspended growth units with rehabilitating the existing mechanical dewatering process. The other small WWTPs were newly constructed and did not need to upgrade.

In Damietta, there were about 23 WWTPs of total capacity about $215000 \mathrm{~m}^{3} / \mathrm{d}$ (individual capacity ranged 600:60,000 $\mathrm{m}^{3} / \mathrm{d}$ ) (Pacer 2009). The treatment processes used in Damietta WWTPs were conventional activated sludge, extended aeration, oxidation ditch, aerated lagoons, and stabilization ponds. Some of these plants (three) have been newly constructed $(2005,2007)$ without needing upgrading and only need qualified operation, maintenance and rehabilitation of construction buildings. Other WWTPs were relatively old (1989 -2002) and needed upgrading of most units and processes in these plants. Most of the limitations and constrains mentioned in the above section were existing in these plant. Therefore, the above suggested corrective actions were used to upgrade the limitations and constrains in Damietta WWTPs.

\section{CONCLUSIONS}

Many of the existing WWTPs reach at capacity and quality to invest in their increasing for meeting stringent quality levels for surface water discharges. WWTPs can be costeffectively upgraded by maximizing the capacity of existing facilities. Upgrading in the most cost-effective manner requires managers to adopt a comprehensive and systematic approach to determine the capacity and performance of existing treatment facilities, identify and evaluate plant upgrade options, and select the option that is most appropriate and cost effective for a particular plant. The procedures for optimizing and upgrading of existing WWTPs include main four steps; i- Evaluation of general processes in the plant, ii- Assessment of individual process, iii- Solution to overcome constrains, and iv- Uncertainty assessment and field-scale testing. Recent advances in WWTPs mathematical modeling of hydraulic and biological processes and the wide availability of computing tools have greatly facilitated integrated evaluation of different alternatives to overcome constrains and bottlenecks in WWTPs. The 
application of upgrading existing Egyptian WWTPs in appropriate procedures increase their life time and therefore saving funds to serve other communities with the required sanitation facilities and improve the quality of life in both rural and urban communities.

\section{REFERENCES}

1. Benedetti, L.; Bixio D.; Vanrolleghem, P.A. (2006), "Assessment of WWTP design and upgrade options: balancing costs and risks of standards' exceedance", Water Sci. Technol. Vol.54(6-7) pp 371-378.

2. Berends, D.H.J.G.; Salem, S.; Van der Roest, H.F.; van Loosdrecht, M.C.M. (2005), "Boosting nitrification with the BABE technology", Water Sci. Technol. Vol.52(4), pp 63-70.

3. Bixio, D.; Parmentier, G.; Rousseau, D.; Verdonck, F.; Meirlaen, J.; Vanrolleghem, P.A.; Thoeye, C. (2002), "A quantitative risk analysis tool for design/simulation of wastewater treatment plants", Water Sci. Technol. Vol.46(45), 301-307.

4. Brdjanovic, D.; Mithaiwala, M.; Moussa, M. S.; Amy, G.; van Loosdrecht, M.C.M. (2007), "Use of modelling for optimization and upgrade of a tropical wastewater treatment plant in a developing Country", Water Sci. Technol. Vol.56(7), pp 21-31

5. Choi, Y ; Johnson, K.; Hayes D. F.; Sung, N, Hua Xu. (2010), "Dissolved organic matter and nitrogen removal by advanced aerated submerged bio-film reactor", Desalination Vol.250, pp368-372.

6. Cote, P.; Masini, M.; Mourato D. (2004), "Comparison of Membrane Options for Water Reuse and Reclamation", Desalination Vol.167, pp 1-11.

7. De-Feo, G.; De-Gisi, S.; Galasso, M. (2008), "Definition of a practical multicriteria procedure for selecting the best coagulant in a chemically assisted primary sedimentation process for the treatment of urban wastewater", Desalination Vol.230, pp 229-238.

8. Diamantis, V. I.; Verstraete W.; Aivasidis A. (2009) Upflow anaerobic clarification tank (UACT) to upgrade existing anaerobic effluents", Water Sci. Technol. Vol.59(12), pp 2411-2419.

9. Dietrich, J.P., Basagaoglu, H., Loge, F., Ginn, T. (2003), "Preliminary assessment of transport processes influencing the penetration of chlorine into wastewater particles and the subsequent inactivation of particle-associated organisms", Water Res. Vol.37, 139-149.

10. Ekama, G. A.; Wentzel, M. C. A (2004), "Predictive model for the reactor inorganic suspended solids concentration in activated sludge systems" Water Res. Vol.38, 4093-4106.

11. El-Sheikh, M. A.; Saleh, H. I.; Salem H. K. (2010a), "Overloading effect on the Performance of Small Wastewater Treatment Plant", Engineering Research J. 127, pp 13-26.

12. El-Sheikh, M.A., Saleh, H.I., El-Quosy, D., Mahmoud, A. (2010b), "Improving water quality in polluted drains with free water surface constructed wetlands", Ecol. Eng. J. 36(10), pp 1478-1484. 
13. Fatone, F.; Battistoni, P.; Bolzonella, D.; Pavan, P.; Cecchi, F (2008), "Longterm experience with an automatic process control for nitrogen removal in membrane bioreactors", Desalination Vol.227 pp 72-84.

14. Gernaey, K.; Rosen, C.; Benedetti, L.; Jeppsson, U. (2005), "Phenomenological modeling of wastewater treatment plant influent disturbance scenarios", Proceedings of $10^{\text {th }}$ International Conference on Urban Drainage, Copenhaghen (Denmark).

15. Grande, T. C.; Augusto, P. A.; Monteiro P.; Barbosa, D. (2010), "Design and application of a membrane bioreactor unit to upgrade and enhance the required performance of an installed wastewater treatment plant", Asia-Pacific J. of Chem. Eng. Vol.5, pp 73-82.

16. Katsenovich, Y.; Shapovalova, L.; But, L.; Ijitskaja M. (2008), "Evaluation of biological pond system modified with submerged planted dams", Ecolog. Eng. J. 33, pp 1-7.

17. Kaya, D.; Dilek, F. B.; Gökçay, C. F. (2007), "Reuse of lagoon effluents in agriculture by post-treatment in a step feed dual treatment process", Desalination Vol.215, pp 29-36.

18. Kim, H.; Gellner, J. W.; Boltz, J. P.; Freudenberg, R. G.; Gunsch, C. K.; Schuler, A. J. (2010), "Effects of integrated fixed film activated sludge media on activated sludge settling in biological nutrient removal systems. Water Res. Vol.44(5), pp 1553-1561.

19. Ladiges, G. and Günner, C. (2003), "Theoretical and practical results of the optimization of Hamburg's WWTPs with dynamic simulation", Water Sci. Technol. Vol.47(12) pp 27-33.

20. Le-Clech, P.; Chen, V.; Fane, T.A.G. (2006), "Fouling in membrane bioreactors used in wastewater treatment", J. Membr. Sci, 284, pp 17-53.

21. Malpei, F.; Bonomo L.; Rozzi, A. (2003), "Feasibility study to upgrade a textile wastewater treatment plant by a hollow fibre membrane bioreactor for effluent reuse", Water Sci. Technol. Vol.47(10) pp 33-39.

22. Martins, M. P.; Pagilla, K. R.; Heijnen, J. J.; van Loosdrecht, M. C. M. (2004), "Bulking Filamentous Sludge- A Critical Review", Water Res. Vol.38, 793-817.

23. McQuarrie, J.; Rutt, K.; Seda, J.; Haegh, M. (2004), "Observations from the first year of full-scale operation -the IFAS/BNR process at the Broomfield wastewater reclamation facility, Broomfield, CO", Proceedings of the Annual Conference of WEFTEC, pp. 274-285.

24. Meriç, S.; Kaptan, D.; Övez, S.; Okten, H. E. (2002), "Operational Problems In Small Wastewater Treatment Plants: A Case Study", Fresenius Environ. Bulletin by PSP., Vol.11 (10b), pp 910-914.

25. Metcalf and Eddy, Inc., Tchobanoglous, G., Burton, F.L., and Stensel, H. (2003), "Wastewater Engineering: Treatment and Reuse", $4^{\text {th }}$ edition. McGraw Hill, New York.

26. Misr Consult; Abdel-Gwad, S. M. (2008), "Mater planning of Sanitation works for Alexandria 2037", Technical report for Egyptian Holding Company of Water Supply and Sanitation Works, Cairo, Egypt.

27. Nelson Environmental Inc. (2008) http://www.nelsonenvironmental.com/PT17_IncreaseHydraulic/default.asp. 
28. Onnis-Hayden, A.; Majed, N.; MaMahon, K.D.; Gu, A.Z., (2008), "Phosphorus removal and PAOs populations at a full-scale integrated fixed-film activated sludge (IFAS) plant", Proceedings of the Water Environmental Federation Annual Conference (WEFTEC), pp. 1-17.

29. Pacer Consult; Ismail, M. (2009), "Mater planning of Water Supply and Sanitation works for Damietta 2037", Technical report for Egyptian Holding Company of Water Supply and Sanitation Works, Cairo, Egypt.

30. Pearce, G. (2008), "Introduction to membranes: An introduction to membrane bioreactors", Filtration \&Separation Journal. Vol.45(1), pp 32-35.

31. Qasim, S. R. (1999), "Wastewater Treatment Plants: Planning, Design and Operation", $2^{\text {nd }}$ edition. Technomic Publishing Co., Lancaster, PA.

a. Reddy, M.P. and Pagilla, K. (2009), "Integrated methods for wastewater treatment plant upgrading and optimization. IWA Publishing, London. UK.

32. Schaar, H.; Clara, M.; Gans, O.; Kreuzinger, N. (2010), "Micropollutant removal during biological wastewater treatment and a subsequentozonation step", Environ. Poll. J. Vol.158, pp 1399-1404.

33. Schuler, A. J. and Jang, H. (2007), "Causes of variable biomass density and its effects on settle-ability in full-scale biological wastewater treatment systems", Environ. Sci. Tech. 41, 1675-1681

34. Sevimli, M.F.; Aydın, A.F.; Öztürk, I.; Sarikaya, H.Z. (2000), "Evaluation of the alternative treatment processes to upgrade Opium alkaloid wastewater treatment", Water Sci. Technol. Vol.41(1) pp 223-230.

a. Sparks, M. (2010), "A small-footprint WWTP uses MBR to manage its erratic flows", Water \& Wastes Digest Vol.50 (1).

35. Steinmann, C., Weinhart, S., Melzer, A., (2003), "A combined system of lagoon and constructed wetland for an effective wastewater treatment", Water Res. Vol.37 (9), 2035-2042.

36. Stephenson, J., Gall, B., Mroczek, C., Newbigging, M., and Parker, J., (2002), "Assessment of Technologies for Screening, Floatable Control, and Screenings Handling", WERF Report: Project 00-CTS-4. Water Environment Research Foundation: Alexandria, VA.

37. Trussell, R. S., Adham, S. and Trussell, R. R. (2005), "Process limits of municipal wastewater treatment with the submerged membrane bioreactor. Environ. Eng. J.Asce, 131, 410.

38. Trussell, R. S.; Rion P. Merlo,R. P.; Slawomir W. Hermanowicz, S. W.; Jenkins, D. (2006), "The Effect of Organic Loading on Process Performance and Membrane Fouling in a Submerged Membrane Bioreactor Treating Municipal Wastewater", Water Res. 40(16), pp 2675-2683.

39. Turovskiy, I.S. and Mathai, P.K. (2006), "Wastewater Sludge Processing", John Wiley \& Sons, New York.

40. U.S. EPA (2003), "Wastewater Technology Fact Sheet - Screening and Grit Removal", EPA 832-F-03-011, U.S. Environmental Protection Agency, Washington, D.C.

41. Vacca, G.; Wand, H.; Nikolausz, M.; Kuschk, P.; Kastner, M. (2005), "Effect of plants and filter materials on bacteria removal in pilot-scale constructed wetlands" Water Res. Vol.39, 1361-1373. 
42. Vandekerckhove, A.; Wim Moerman, W.; Van-Hulle, S.W.H. (2008), "Fullscale modelling of a food industry wastewater treatment plant in view of process upgrade", Chem. Eng. J. Vol.135, pp 185-194.

43. Wahlberg, E.J. (2001), "WERF/CRTC Protocols for Evaluating Secondary Clarifier Performance", WERF Report: Project 00-CTS-1; Water Environment Research Foundation, Alexandria, VA.

44. Wahlberg, E.J. (2006), "How Critical Wastewater Characteristics Affect Primary Clarifier Performance", WERF Report: Treatment Processes (00-CTS-2). IWA Publishing, London.

45. Wisniewski, C. (2007), "Membrane bioreactor for water reuse", Desalination, Vol.203, pp 15-19.

46. Yang, W.; Cicek, N.; Ilg, J. (2006), "State-of-the-art of membrane bioreactors: worldwide research and commercial applications in North America", J. Membr. Sci., Vol.207, pp 201-211.

\section{تحسين أداء وزيادة سعة محطات معالجة الصرف الصحي}

تقل كفاءة ونوعية المياه المعالجة مع زيادة عمر محطات معالجة الصرف الصحي بينما تزيد تشدد اشتراطات الأمان والمحافظة على البيئة لتحسن نوعية الحياة بصفة عامة. ولذلك فانه من الضروري العمل على تحسين أداء وزيادة سعة محطات معالجة الصرف الصحي القائمة بطربقة اقتصادية لتحسين نوعية المياه المعالجة لتتطابق مع القوانين البيئية الجديدة. وفي هذا البحث يتم استعراض طرق المعالجة المختلفة واهم المشاكل الموجودة بها للتغلب عليها. وأيضا تم اقتراح الخطوات الواجب إتباعها لبحث تحسين أداء وزيادة سعة محطات المعالجة القائمة متضمنا المدخل التتظيمي لتحديد سعة وأداء العمليات القائمة بالمحطة والمناطق التي تعاني من قصور ووضع البدائل للتغلب عليها مع تقييم هذه البدائل لاختيار الأفضل من ناحية الأداء والتكلفة. وقد تم استخدام هذه الطرق لتحسين أداء وزيادة سعة محطات معالجة الصرف الصحي في محافظتي الإسكندرية ودمياط أثناء عمل المخطط العام للصرف الصحي هـ مه في هذه المحافظات. 